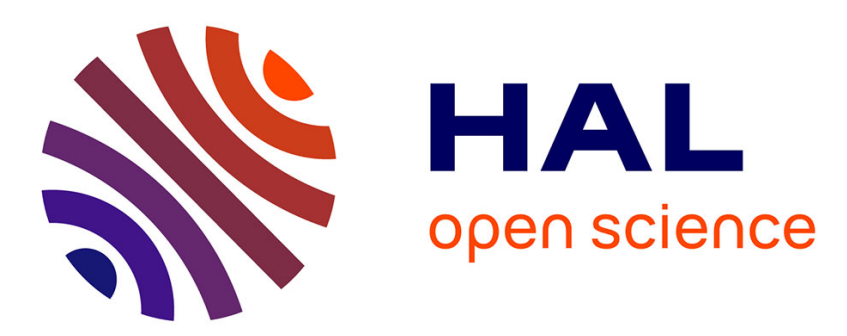

\title{
Colloidal $\alpha$-Al_2O_3, Europium(III) and humic substances interactions: A macroscopic and spectroscopic study
}

\author{
Noémie Janot, Marc F. Benedetti, Pascal E. Reiller
}

\section{To cite this version:}

Noémie Janot, Marc F. Benedetti, Pascal E. Reiller. Colloidal $\alpha$-Al_2O_3, Europium(III) and humic substances interactions: A macroscopic and spectroscopic study. Environmental Science and Technology News and Research Notes, 2011, 45 (8), pp.3224-3230. 10.1021/es102592a . cea-00586155

\section{HAL Id: cea-00586155 \\ https://hal-cea.archives-ouvertes.fr/cea-00586155}

Submitted on 31 Aug 2021

HAL is a multi-disciplinary open access archive for the deposit and dissemination of scientific research documents, whether they are published or not. The documents may come from teaching and research institutions in France or abroad, or from public or private research centers.
L'archive ouverte pluridisciplinaire HAL, est destinée au dépôt et à la diffusion de documents scientifiques de niveau recherche, publiés ou non, émanant des établissements d'enseignement et de recherche français ou étrangers, des laboratoires publics ou privés. 


\title{
Colloidal $\alpha-\mathrm{Al}_{2} \mathrm{O}_{3}$, Europium(III) and Humic Substances Interactions: A Macroscopic and Spectroscopic Study
}

\author{
Noémie Janot ${ }^{1,2}$, Marc F. Benedetti, ${ }^{1}$ Pascal E. Reiller ${ }^{2, *}$
}

\begin{abstract}
${ }^{1}$ Laboratoire de Géochimie des Eaux, Université Paris Diderot, IPGP UMR CNRS 7154, 75025 Paris, Cedex 13, France,
${ }^{2}$ Commissariat à l’Énergie Atomique, CE Saclay, CEA/DEN/DANS/DPC/SECR, Laboratoire de Spéciation des Radionucléides et des Molécules, Bâtiment 391 PC 33, F-91191 Gif-sur-Yvette CEDEX, France.

*e-mail: pascal.reiller@cea.fr.
\end{abstract}

ABSTRACT $\mathrm{Eu}(\mathrm{III})$ sorption onto $\alpha-\mathrm{Al}_{2} \mathrm{O}_{3}$ in the presence of purified Aldrich humic acid (PAHA) is studied by batch experiments and time-resolved laser-induced luminescence spectroscopy of $\mathrm{Eu}$ (III). Experiments are conducted at varying $\mathrm{pH}$, at $0.1 \mathrm{~mol} / \mathrm{L} \mathrm{NaClO}_{4}, 10^{-6} \mathrm{~mol} / \mathrm{L} \mathrm{Eu}(\mathrm{III}), 1 \mathrm{~g} / \mathrm{L} \alpha-\mathrm{Al}_{2} \mathrm{O}_{3}$ and 28 $\mathrm{mg} / \mathrm{L}$ PAHA. Adsorption of $\mathrm{Eu}(\mathrm{III})$ presents the expected $\mathrm{pH}$-edge at 7, which is modified by addition of PAHA. Presence of $\mathrm{Eu}(\mathrm{III})$ slightly increases PAHA sorption throughout the $\mathrm{pH}$ range. The evolutions of luminescence spectra and decay times of the binary systems, i.e. $\mathrm{Eu}(\mathrm{III}) / \alpha-\mathrm{Al}_{2} \mathrm{O}_{3}$ and $\mathrm{Eu}(\mathrm{III}) / \mathrm{PAHA}$, indicate a progressive surface- and humic-complexation with increasing $\mathrm{pH}$. The typical bi-exponential luminescence decay in $\mathrm{Eu}(\mathrm{III}) / \mathrm{PAHA}$ system is also recorded; the fastest deactivation depending barely on $\mathrm{pH}$. In ternary $\mathrm{Eu}(\mathrm{III}) / \mathrm{PAHA} / \alpha-\mathrm{Al}_{2} \mathrm{O}_{3}$ system, the existence of a luminescence biexponential decay for all $\mathrm{pH}$ means that $\mathrm{Eu}(\mathrm{III})$ is always in the direct neighborhood of the humic substance. Below pH 7, the spectra of the ternary system $\left(\mathrm{Eu}(\mathrm{III}) / \mathrm{PAHA} / \alpha-\mathrm{Al}_{2} \mathrm{O}_{3}\right)$ are not different from the ones of $\mathrm{Eu}(\mathrm{III}) / \mathrm{PAHA}$ system, implying the same complex symmetry. Nevertheless, the increase of luminescence decay time points to a change in PAHA conformation onto the surface.

\section{KEYWORDS}

Humic acid; Europium; Alumina; Luminescence; Sorption; Ternary complex

\section{BRIEFS}

Influences of humic acid and $\mathrm{pH}$ on retention and speciation of $\mathrm{Eu}(\mathrm{III})$ in contact with colloidal $\alpha-\mathrm{Al}_{2} \mathrm{O}_{3}$ are analyzed by macroscopic batch experiments and time-resolved laser luminescence spectroscopy. 


\section{Introduction}

Natural organic matter $(\mathrm{NOM})$ interactions with mineral colloids in soils partly control the speciation and migration of heavy metals as well as nanoparticles in the environment, and notably of lanthanides and actinides ${ }^{1,2}$. The modeling of ternary systems consisting of metal-NOM-mineral surface has often led to discrepancies. Particularly, the additivity of the binary systems was not fulfilled ${ }^{3,4}$. In some examples, successful modeling exercises were proposed for fulvic acids ${ }^{5,6}$. These samples can be assumed to be more or less similar to simple organic molecules ${ }^{7}$. Fulvic acids (FA) sorption is stable or decreases with increasing ionic strength ${ }^{8-10}$, whereas sorption of humic acids (HA) onto oxides increases with ionic strength $^{8,10,11}$. Hence, it is still difficult to propose interpretations of HA effects on the modeling of ternary systems in a wide parametric space ${ }^{4,12}$. Moreover, heterogeneous composition and nature of $\mathrm{HA}^{13,14}$, and constant modification of $\mathrm{HA}$ aggregates with physico-chemical conditions of the solution ${ }^{15}$ or due to sorption ${ }^{16,17}$ do not ease the modeling of these systems. The accurate understanding and description of the HAcontaining systems are still under discussion. A better description of these systems is still needed to improve the understanding of the behavior of metals and nanoparticles in the environment.

One way to obtain both macroscopic and spectroscopic information on $\mathrm{Ln} / \mathrm{An}$ (III) sorption onto mineral surfaces is through time-resolved laser-induced luminescence spectroscopy (TRLS). Due to their luminescence properties, one can have a direct insight on speciation of the ions in solution, in contact with humic substances ${ }^{18-23}$ as well as sorbed onto mineral surfaces ${ }^{24,25}$ or in ternary systems ${ }^{26}$. Measurements can be made at low metal ion concentration, to get as close as possible to environmental concentrations. TRLS has been used in either combination of the ternary systems, but up to now no direct comparison has been done between the two binary systems and the corresponding ternary system in a whole range of $\mathrm{pH}$.

The aim of this study was to investigate the influence of Aldrich humic acid on the behavior and the speciation of a lanthanide, Europium(III), as a chemical analog of An(III), in presence or absence of $\alpha-\mathrm{Al}_{2} \mathrm{O}_{3}$. Aluminum oxides are not the more frequent mineral surfaces found in the environment, but their aluminol surface sites are part of aluminosilicates reactive sites, very abundant in natural systems. Besides, its transparency for light allows spectroscopic measurements with mineral in solution, contrary to iron oxides ${ }^{24}$. Macroscopic and spectroscopic experiments have been carried out to see the influence of $\mathrm{pH}$ on the evolution of the different systems.

\section{Experimental Section}

Materials Commercial Aldrich humic acid was purified (PAHA) according to ref 27. Stock suspension at $1 \mathrm{~g} / \mathrm{L}$ has been prepared by diluting PAHA in $\mathrm{NaOH}$ ( $\mathrm{pH}$ around 10) in order to completely dissolve the sample. The solution was then stored in the dark under $\mathrm{N}_{2}$. Proton exchange capacity was determined by potentiometry and found at $6.12 \mathrm{eq} / \mathrm{kg}^{28}$. Alumina $\left(\alpha-\mathrm{Al}_{2} \mathrm{O}_{3}\right)$ was purchased from Interchim (pure $99.99 \%$, size fraction $200-500 \mathrm{~nm}$ ). The solid was washed thrice with carbonate-free $\mathrm{NaOH}$ and thrice with Millipore water before drying and storage at room temperature under $\mathrm{N}_{2}$ atmosphere according to ref 29. The specific surface area measured by $\mathrm{N}_{2}-$ BET method was $15 \mathrm{~m}^{2} / \mathrm{g}$. Point of zero charge was determined by acid-base titrations and found at $\mathrm{pH}=9.4$ (data not shown). Europium(III) stock solution $\left(10^{-3} \mathrm{~mol} / \mathrm{L}\right)$ was obtained from the dissolution of $\mathrm{Eu}_{2} \mathrm{O}_{3}$ (Johnson Matthey, 99.99\%) in $\mathrm{HClO}_{4}$. All solutions were prepared using freshly boiled milli-Q water. 
Methods Batch contact experiments were conducted in $10.4 \mathrm{ml}$ Beckman centrifugation tubes (355603). The different concentrations of compounds were $1 \mathrm{~g} / \mathrm{L}$ of $\alpha-\mathrm{Al}_{2} \mathrm{O}_{3}, 10^{-6} \mathrm{~mol} / \mathrm{L}$ of $\mathrm{Eu}(\mathrm{III})$ and $28 \mathrm{mg} / \mathrm{L}$ of PAHA, which assured a complete complexation of $\mathrm{Eu}$ (III) by PAHA (see refs 23 and 30 confirmed by Supporting Information (SI) Figure S1). First solid $\alpha-\mathrm{Al}_{2} \mathrm{O}_{3}$, then PAHA and Eu(III) stock solutions and finally freshly degazed electrolyte solutions were weighed, with no specific contact time applied between additions. To minimize carbonation of the systems, nitrogen was swept on the top of the solution before closing the tubes. Ionic strength was fixed at $0.1 \mathrm{~mol} / \mathrm{L} \mathrm{NaClO}_{4}$. The $\mathrm{pH}$ values of the solutions were adjusted by addition of fresh $0.1 \mathrm{~mol} / \mathrm{L} \mathrm{HClO}_{4}$ and $\mathrm{NaOH}$ solutions. They were measured using one combined glass electrode (Radiometer Analytical) connected to a Radiometer Analytical pH Meter. To prevent $\mathrm{KClO}_{4}$ precipitation in the electrode frit, the electrode filling solution was modified with $\mathrm{NaCl}$ at $0.1 \mathrm{~mol} / \mathrm{L}$. The $\mathrm{pH}$ electrode was calibrated using buffer solutions ( $\mathrm{pH} 4.01,7.01$, and 10.00). The solutions were applied to three dimensional stirring for 3 days of equilibration at room temperature before $\mathrm{pH}$ measurements and analyses.

After equilibration, subsamples $(2.4 \mathrm{ml})$ were taken from the centrifugation tubes and analyzed in quartz cuvettes $(10 \mathrm{~mm})$. Preliminary experiments showed no significant differences between aliquots taken from one same tube. $\mathrm{Eu}$ (III) laser-induced properties were studied in contact with either PAHA, or $\alpha-\mathrm{Al}_{2} \mathrm{O}_{3}$, or both components using TRLS. The excitation laser beam was generated by a $355 \mathrm{~nm}$ tripled output of a Continuum Nd-YAG laser, coupled to an optical parametric oscillator system (Panther II, Continuum, USA). The time-resolved luminescence signal is collected at $90^{\circ}$ and focused into an Acton spectrometer (slit $1 \mathrm{~mm}$ ) equipped with 600 lines/mm grating. For the time- resolved detection, the luminescence signal was collected during a gate width $\mathrm{L}=300 \mu \mathrm{s}$, at an initial gate delay $\mathrm{D}=10 \mu \mathrm{s}$ after the excitation by a laser flash. To increase the signal to noise ratio, 1000 accumulations were performed for each spectrum. To avoid the aggregation and settling of the samples occurring in $\alpha-\mathrm{Al}_{2} \mathrm{O}_{3}$-containing systems, these samples were manually shaken between two measurements. All luminescence measurements were performed at ambient temperature $\left(21^{\circ} \mathrm{C} \pm 2\right)$. The excitation wavelength was set at $\lambda_{\text {exc }}=393.8 \mathrm{~nm}$. The observed luminescence corresponds to the transitions of the ${ }^{5} \mathrm{D}_{0}$ excited state to the ground ${ }^{7} \mathrm{~F}_{\mathrm{j}}$ manifold ${ }^{31}$. They are the ${ }^{5} \mathrm{D}_{0} \rightarrow^{7} \mathrm{~F}_{0}$ forbidden for magnetic and electric reasons $\left(\lambda_{\max } \approx 580 \mathrm{~nm}\right)$, the ${ }^{5} \mathrm{D}_{0} \rightarrow{ }^{7} \mathrm{~F}_{1}$ magnetic dipole transition $\left(\lambda_{\max } \approx 593\right.$ $\mathrm{nm})$, and the ${ }^{5} \mathrm{D}_{0} \rightarrow{ }^{7} \mathrm{~F}_{2}$ "hypersensitive" transition $\left(\lambda_{\max } \approx 615 \mathrm{~nm}\right),{ }^{32,33}$ (SI Figures S1 and S2).

To characterize adsorbed amounts of PAHA and $\mathrm{Eu}(\mathrm{III})$ onto $\alpha-\mathrm{Al}_{2} \mathrm{O}_{3}$, after equilibration the solutions were ultra-centrifuged at $60000 \mathrm{rpm}$ during $2 \mathrm{~h}$. Concentration of PAHA in the supernatant was measured by a Shimadzu TOCVCSH analyzer, calibrated in concentration of PAHA between 0 and $50 \quad \mathrm{mg}_{\mathrm{HA}} / \mathrm{L}$. The quantification of non-sorbed $\mathrm{Eu}(\mathrm{III})$ was made using TRLS using the standard addition method ${ }^{34}$, diluting an aliquot of the supernatant in $\mathrm{K}_{2} \mathrm{CO}_{3}$ $3 \mathrm{~mol} / \mathrm{L}$. This method allow determination of $\mathrm{Eu}(\mathrm{III})$ concentration down to $10^{-9} \mathrm{~mol} / \mathrm{L}$.

\section{Results and Discussion}

Macroscopic Adsorption Experiments Figure 1 shows the influences of $\mathrm{pH}$ and $\mathrm{Eu}(\mathrm{III})$ on PAHA adsorption onto $\alpha-\mathrm{Al}_{2} \mathrm{O}_{3}$. The humic acid sorption is typically decreasing when $\mathrm{pH}$ increases and $\alpha-\mathrm{Al}_{2} \mathrm{O}_{3}$ surface becomes less positively charged, as for other oxides ${ }^{8,35,36}$. Adsorption is nevertheless significant throughout the $\mathrm{pH}$ range, going from $1.24 \mathrm{mg}_{\mathrm{HA}} / \mathrm{m}^{2}$ at $\mathrm{pH} 4.0$ (i.e. $76 \%$ of initial amount of PAHA) to $0.61 \mathrm{mg}_{\mathrm{HA}} / \mathrm{m}^{2}$ at $\mathrm{pH} 8.8$ (i.e. $37 \%$ ). 
Figure 1. Surface concentration of PAHA on $\alpha-\mathrm{Al}_{2} \mathrm{O}_{3}$ depending on $\mathrm{pH}$, with $(\mathbf{O})$ or without $(\diamond)$ $\mathrm{Eu}(\mathrm{III}) . \mathrm{C}($ Alumina $)=1 \mathrm{~g} / \mathrm{L}, \mathrm{C}(\mathrm{PAHA})_{\text {initial }}=26.5 \pm 2 \mathrm{mg} / \mathrm{L},[\mathrm{Eu}(\mathrm{III})]_{\text {initial }}=10^{-6} \mathrm{~mol} / \mathrm{L}, I=0.1 \mathrm{~mol} / \mathrm{L}$ $\mathrm{NaClO}_{4}$. Error bars correspond to $2 \sigma$.

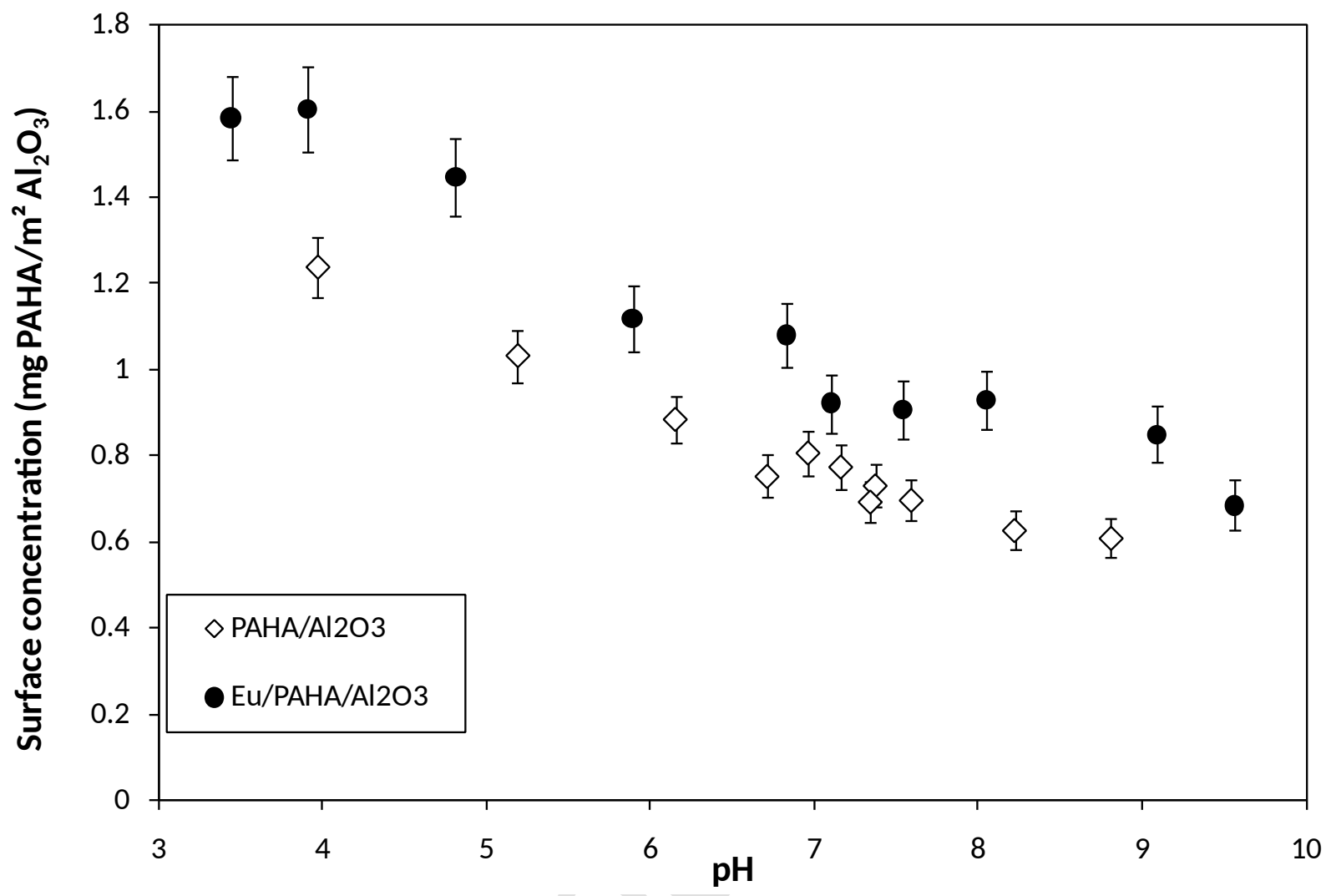

The presence of Eu(III) seems to homogeneously increase the retention of the humic substance onto $\alpha-\mathrm{Al}_{2} \mathrm{O}_{3}$ surface throughout the $\mathrm{pH}$ range studied. For the ternary system, PAHA sorption goes from $1.60 \mathrm{mg}_{\mathrm{HA}} / \mathrm{m}^{2}$ at $\mathrm{pH} 3.9$ (i.e. $88 \%$ ) to 0.69 $\mathrm{mg}_{\mathrm{HA}} / \mathrm{m}^{2}$ at $\mathrm{pH} 9.6$ (i.e. $38 \%$ ).

Schlautman and Morgan reported an increase of HA sorption onto $\gamma-\mathrm{Al}_{2} \mathrm{O}_{3}$ in presence of $\mathrm{Ca}^{2+}$ between $\mathrm{pH} 4$ and 10 for different coverage rates (from 0.1 to $5.6 \mathrm{mg}_{\mathrm{HA}} / \mathrm{m}^{2}$ ) in $0.1 \mathrm{~mol} / \mathrm{L} \mathrm{NaCl}$, but did not observe this increase in their $\mathrm{Ca} / \mathrm{FA}$ /alumina system $^{8}$. Krepelova et al. also noticed this increase in sorption of HA in a $\mathrm{U}(\mathrm{VI}) / \mathrm{HA} / \mathrm{kaolinite}$ system (initial ratio of 0.32 $\mathrm{mg}_{\mathrm{HA}} / \mathrm{m}^{2}$ ), but only at $0.01 \mathrm{~mol} / \mathrm{L} \mathrm{NaClO}_{4}$ and not at $0.1 \mathrm{~mol} / \mathrm{L}^{37}$. The same trend was reported by Christl and Kretzschmar when studying fulvic acid sorption in a $\mathrm{Cu} / \mathrm{FA} /$ hematite system in 0.01 $\mathrm{NaNO}_{3}$ media (initial ratio of $0.68 \mathrm{mg}_{\mathrm{FA}} / \mathrm{m}^{2}$ ), but not at 0.03 and $0.1 \mathrm{~mol} / \mathrm{L}^{3}$. Weng et al. observed an increase of $\mathrm{FA}$ sorption in a $\mathrm{Cu} / \mathrm{FA} /$ goethite system at $0.1 \mathrm{~mol} / \mathrm{L} \mathrm{NaNO}_{3}$ for two initial FA concentrations, i.e 0.13 and $0.80 \mathrm{mg}_{\mathrm{FA}} / \mathrm{m}^{2}{ }^{5}$. This latter value is closer to our organic matter-tomineral ratio, i.e. $1.86 \mathrm{mg}_{\mathrm{HA}} / \mathrm{m}^{2}$. However, the direct comparison between HA and FA may not be straightforward regarding the influence of ionic strength on FA and HA sorption ${ }^{8-11}$. This increase of HS adsorption in ternary systems is often interpreted as the formation of a metal bridge between the negatively charge surface and humic binding sites, which is unlikely at $\mathrm{pH} 4$, i.e. before the sorption edge of $\mathrm{Eu}(\mathrm{III})$. Schlautman and Morgan attribute this increase at low to neutral $\mathrm{pH}$ to hydrophobic bonding, polyvalent ions screening the repulsive charges of the humic molecule at the mineral surface and thus enhancing $\mathrm{HA}$ adsorption ${ }^{8}$. One could also propose the variation of humic conformation induced by ionic strength $^{38,39}$ or agglomeration induced by 
complexation of $\operatorname{Ln}(\mathrm{III})^{40,41}$. The ratios between the different components, as well as the metal charge, may also play a major role.

Figure 2 shows the influence of $\mathrm{pH}$ and PAHA on $\mathrm{Eu}(\mathrm{III})$ adsorption onto $\alpha-\mathrm{Al}_{2} \mathrm{O}_{3}$. In the binary $\mathrm{Eu}(\mathrm{III}) / \alpha-\mathrm{Al}_{2} \mathrm{O}_{3}$ system, the adsorption curve shows the expected sorption-edge around $\mathrm{pH} 7$ for $\mathrm{Ln} / \mathrm{An}(\mathrm{III})^{29,42-44}$, increasing from $3.5 \times 10^{-6}$ $\mathrm{mmol}_{\mathrm{Eu}} / \mathrm{m}^{2}$ retained at $\mathrm{pH} 4.4$, that is, $5 \%$ of initial amount of $\mathrm{Eu}$ (III), to $6.4 \times 10^{-6} \mathrm{mmol}_{\mathrm{Eu}} / \mathrm{m}^{2}$ at $\mathrm{pH}$ 9.8 (i.e. $\approx 100 \%$ ). Inorganic speciation of $\mathrm{Eu}(\mathrm{III})$ using data from Hummel et al. ${ }^{45}$ is shown in SI Figure $\mathrm{S} 3 \mathrm{a} . \mathrm{Eu}^{3+}$ is predominant up to $\mathrm{pH} 7$, and then hydrolyzed species become the predominant ones. Eu(III) adsorption increases just before its first hydrolysis, as previously observed by Bradbury and Baeyens onto illite ${ }^{46}$. They have shown that surface complexation of metals is closely related to their first hydrolysis constants ${ }^{47}$. As expected, presence of HA changes $\mathrm{Eu}(\mathrm{III})$ behavior: at $\mathrm{pH}<6$, PAHA enhances $\mathrm{Eu}(\mathrm{III})$ retention onto the surface ${ }^{42,43}$. Around their first acidity constants, PAHA molecules, negatively charged, adsorb onto the positively charged oxide surface at low $\mathrm{pH}$ values, and $\mathrm{Eu}(\mathrm{III})-\mathrm{PAHA}$ complexes adsorb onto the surface. The Eu(III)PAHA speciation under our experimental conditions determined by ECOSAT ${ }^{48}$ software and generic data from Milne ${ }^{30}$ is shown in SI Figure $\mathrm{S} 3 \mathrm{~b}$.

At $\mathrm{pH}$ greater than 7, the presence of PAHA is slightly decreasing Eu adsorption compared to the binary system, as previously observed in other metal-oxide systems $s^{26,35,42,43,49}$. This is commonly thought to be due to the progressive decrease of HA sorption with increasing $\mathrm{pH}$ and the resulting competition for $\mathrm{Eu}(\mathrm{III})$ between adsorbed HA and HA in solution. At $\mathrm{pH} \geq 8$, the adsorption of $\mathrm{Eu}(\mathrm{III})$ onto the surface increases slightly again, resulting from the competition of $\mathrm{Eu}$ (III) between $\alpha-\mathrm{Al}_{2} \mathrm{O}_{3}$ surface, surface-adsorbed PAHA and dissolved PAHA.

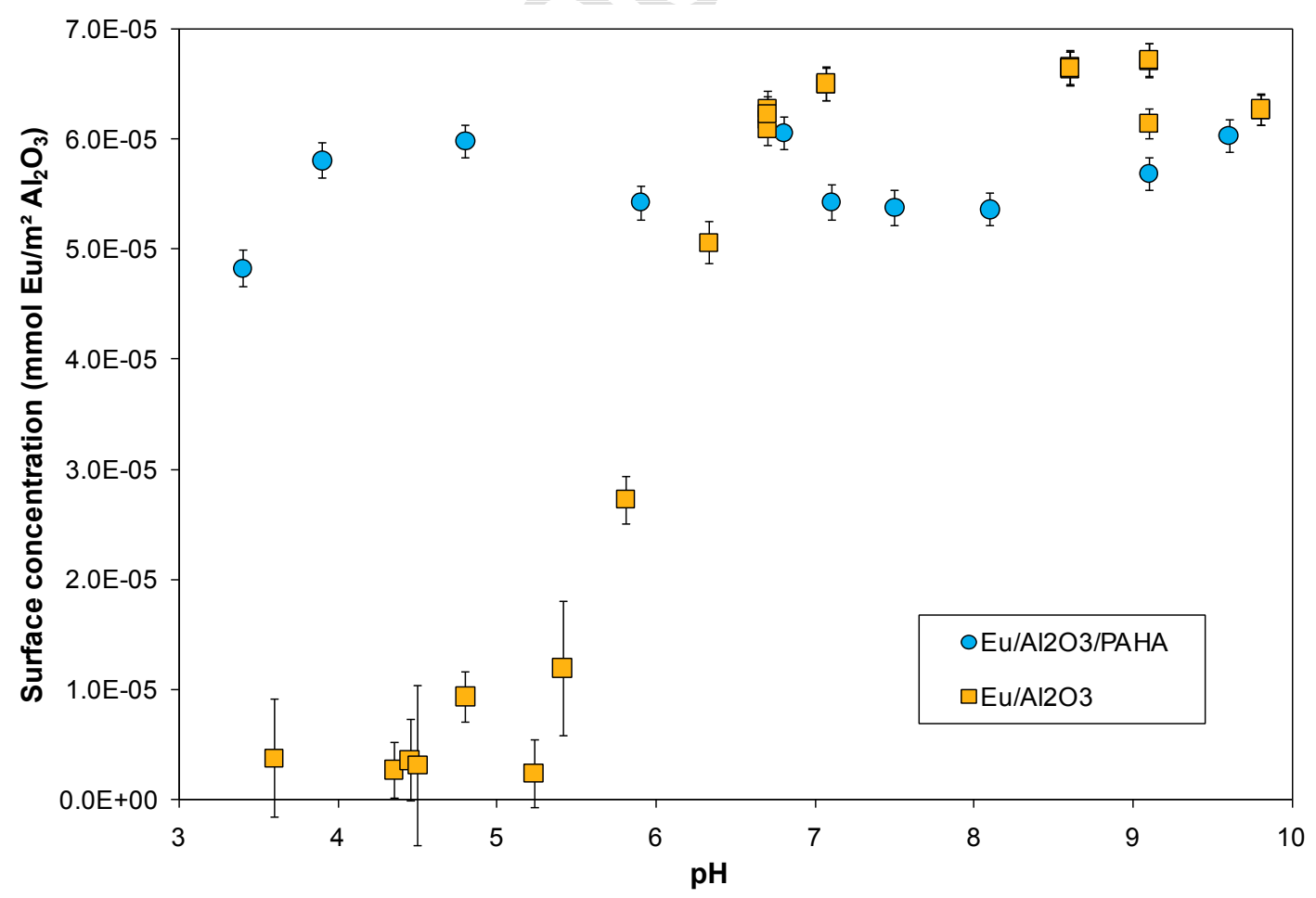

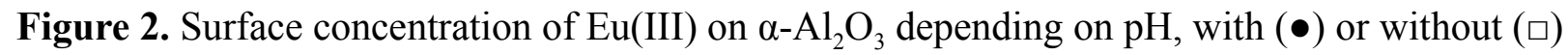
PAHA. $\mathrm{C}($ Alumina $)=1 \mathrm{~g} / \mathrm{L}, \mathrm{C}(\mathrm{PAHA})_{\text {initial }}=28 \mathrm{mg} / \mathrm{L},[\mathrm{Eu}(\mathrm{III})]_{\text {initial }}=10^{-6} \mathrm{~mol} / \mathrm{L}, I=0.1 \mathrm{~mol} / \mathrm{L} \mathrm{NaClO}_{4}$. Error bars correspond to $2 \sigma$. 
Eu(III) Speciation Analysis Eu(III) luminescence spectra and decay times in the different systems were analyzed by TRLS at different $\mathrm{pH}$. The peak shapes and asymmetry ratios, i.e. ${ }^{5} \mathrm{D}_{0} \rightarrow{ }^{7} \mathrm{~F}_{2}$ to ${ }^{5} \mathrm{D}_{0} \rightarrow{ }^{7} \mathrm{~F}_{1}\left({ }^{7} \mathrm{~F}_{2} /{ }^{7} \mathrm{~F}_{1}\right)$, provide information on $\mathrm{Eu}(\mathrm{III})$ speciation $^{31}$. The calculation of ratios avoids us the necessity to take into account light attenuation for comparing the different systems, as this information is independent from the total luminescence recorded. The evolution of these ratios depending on $\mathrm{pH}$ is shown in Figure 3 for the different systems. Luminescence decay times have been measured with delay steps of 10 to $25 \mu$ s. They are plotted against $\mathrm{pH}$ for the different systems in Figure 4. They have been adjusted to the decay of ${ }^{5} \mathrm{D}_{0} \rightarrow^{7} \mathrm{~F}_{1}$ transition area (between 585 and $600 \mathrm{~nm})^{19,20,22}$, as it is less sensitive to solution conditions ${ }^{32,33}$.

Binary Systems. As seen in Figure 3 , the ${ }^{7} \mathrm{~F}_{2} /{ }^{7} \mathrm{~F}_{1}$ ratio in $\mathrm{Eu}(\mathrm{III}) / \alpha-\mathrm{Al}_{2} \mathrm{O}_{3}$ system increases from 0.6 at $\mathrm{pH} 4.4$ to 2.0 at $\mathrm{pH} 8.8$. When $\mathrm{pH}$ increases, the possibility for $\mathrm{Eu}(\mathrm{III})$ to form surface complexes on $\alpha-\mathrm{Al}_{2} \mathrm{O}_{3}$ is also increasing, as seen in macroscopic data. The ${ }^{5} \mathrm{D}_{0} \rightarrow{ }^{7} \mathrm{~F}_{0}$ transition appears for $\mathrm{pH}>5.5$, indicating a loss of symmetry in the ion environment above this $\mathrm{pH}$ value, which corresponds to the beginning of Eu(III) adsorption (Figure 2).

Mono-exponential luminescence decay time $(\tau)$ of $\mathrm{Eu}(\mathrm{III})$ ions in binary $\mathrm{Eu}(\mathrm{III}) / \alpha-\mathrm{Al}_{2} \mathrm{O}_{3}$ system increases with $\mathrm{pH}$, from $\tau=120 \pm 3 \mu$ s at $\mathrm{pH} 4.4$ to $\tau=277 \pm 5 \mu$ s at $\mathrm{pH} 8.8$ (Figure 4 ). A greater luminescence decay time means that there is a higher probability for an excited Eu ion to emit a photon than to lose energy through other nonradiative pathways, i.e. quenching by water molecules, $-\mathrm{OH}$ groups, and $-\mathrm{NH}$ groups. The increase of $\tau$ is interpreted as the substitution of water molecules in the first coordination sphere of the luminescent ion $^{50,51}$. Here, the increase of $\tau$ from $120 \mu$ s to $277 \mu$ s would correspond to the

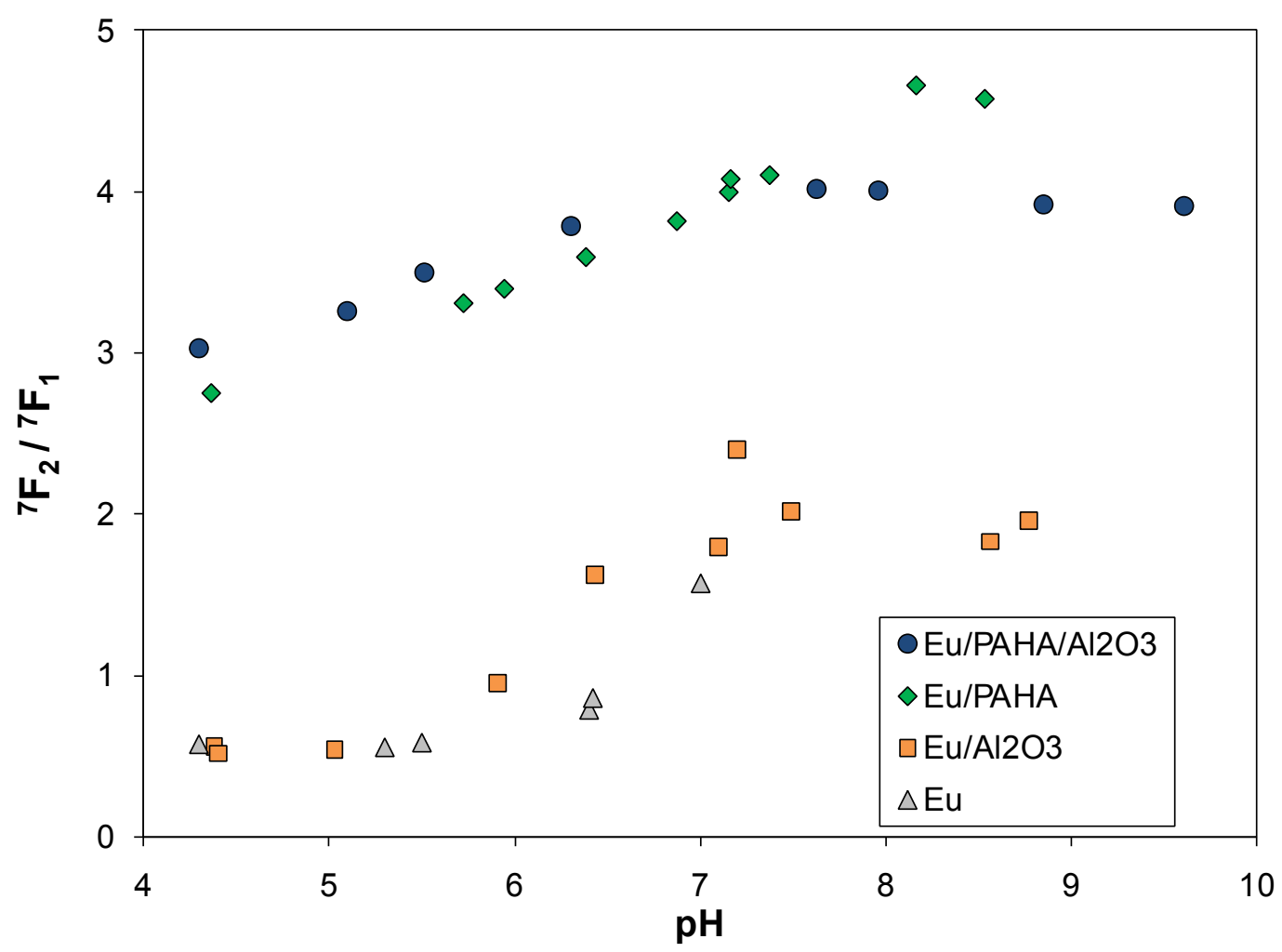

Figure 3. Evolution of ${ }^{5} \mathrm{D}_{0} \rightarrow{ }^{7} \mathrm{~F}_{2} / 5 \mathrm{D}_{0} \rightarrow{ }^{7} \mathrm{~F}_{1}$ ratio depending on $\mathrm{pH}: \mathrm{C}\left(\alpha-\mathrm{Al}_{2} \mathrm{O}_{3}\right)=1 \mathrm{~g} / \mathrm{L}, \mathrm{C}(\mathrm{PAHA})_{\text {intial }}=$ $28 \mathrm{mg} / \mathrm{L},[\mathrm{Eu}(\mathrm{III})]_{\text {intial }}=10^{-6} \mathrm{~mol} / \mathrm{L}, I=0.1 \mathrm{~mol} / \mathrm{L} \mathrm{NaClO}{ }_{4}$. 


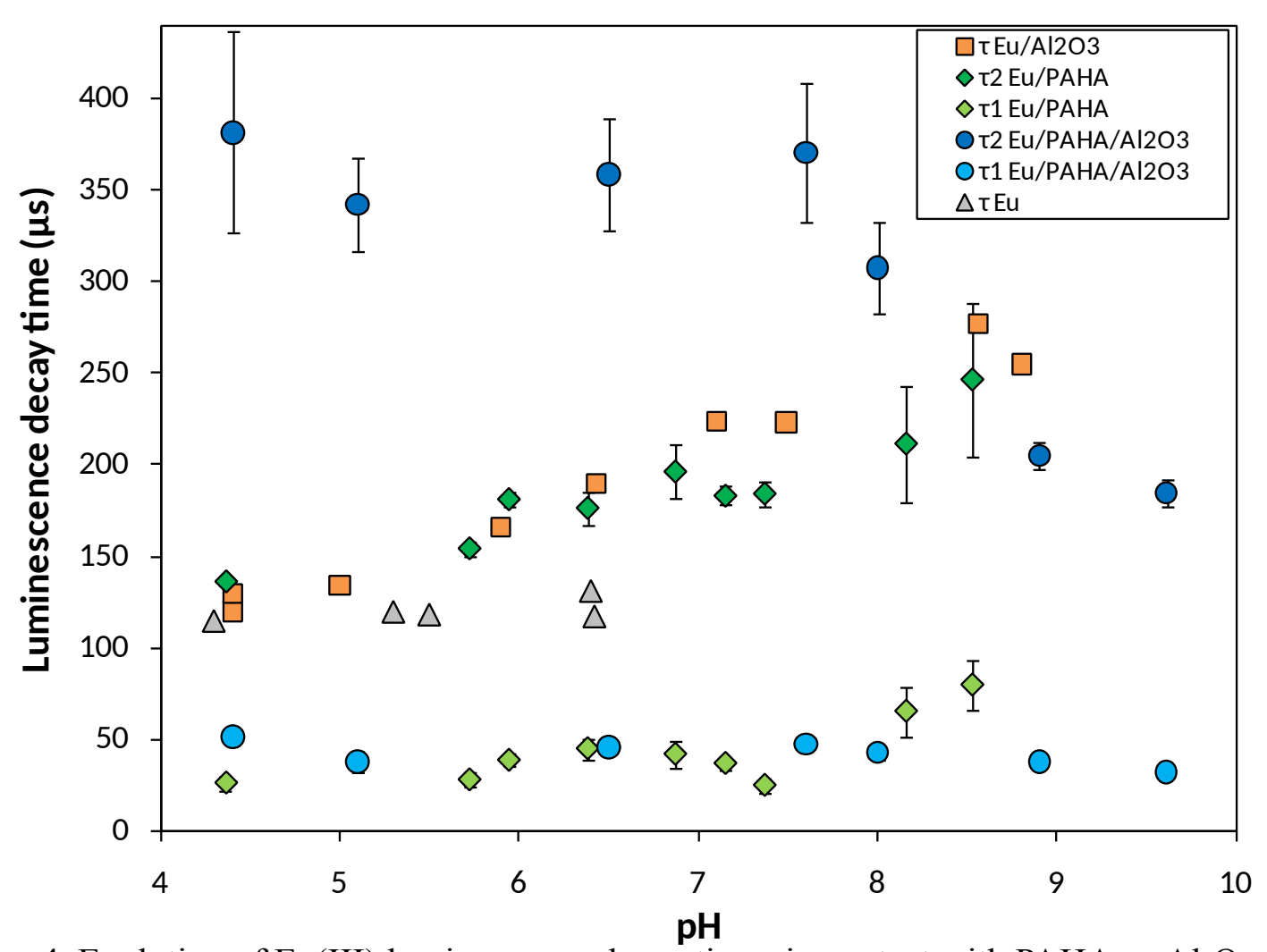

Figure 4. Evolution of $\mathrm{Eu}(\mathrm{III})$ luminescence decay times in contact with $\mathrm{PAHA}, \alpha-\mathrm{Al}_{2} \mathrm{O}_{3}$ or both compounds depending on $\mathrm{pH} ; \mathrm{C}($ Alumina $)=1 \mathrm{~g} / \mathrm{L}, \mathrm{C}(\text { PAHA })_{\text {initial }}=28 \mathrm{mg} / \mathrm{L},[\mathrm{Eu}(\mathrm{III})]_{\text {intital }}=10^{-6} \mathrm{~mol} / \mathrm{L}$, $I=0.1 \mathrm{~mol} / \mathrm{L} \mathrm{NaClO}_{4}$; Error bars correspond to $2 \sigma$.

loss of 5 water molecules according to ref 52 . Water molecules are supposed to be excluded from the first coordination sphere of $\mathrm{Eu}(\mathrm{III})$ when it forms surface complexes onto $\alpha-\mathrm{Al}_{2} \mathrm{O}_{3}$. Nevertheless, this number must be taken carefully, as previous studies have shown that the relationship between luminescence decay time and the number of surrounding water molecules may depend on the system studied ${ }^{53}$. One should better consider the more complete relationship determined otherwise ${ }^{50,51}$, which requires the measure of the decay time in $\mathrm{D}_{2} \mathrm{O}$ in all the three systems, which was out of the scope of this study.

In Eu(III)/PAHA systems, ${ }^{7} \mathrm{~F}_{2} /{ }^{7} \mathrm{~F}_{1}$ increases from 2.6 at $\mathrm{pH} 4.1$ to 4.6 at $\mathrm{pH} 8.5$ (Figure 3). There is apparently a continuous evolution of the chemical environment of $\mathrm{Eu}(\mathrm{III})$ throughout the $\mathrm{pH}$ range. This could be linked to the increase of Eu(III) binding to PAHA with increasing $\mathrm{pH}$ and the evolution of the type of bonding of Eu(III) within the humic structure ${ }^{54}$. The evolution parallels the
$\mathrm{Eu}(\mathrm{III}) / \alpha-\mathrm{Al}_{2} \mathrm{O}_{3}$ system at a different magnitude, with ${ }^{7} \mathrm{~F}_{2} /{ }^{7} \mathrm{~F}_{1}>1$ at all $\mathrm{pH}$. In presence of PAHA, the ${ }^{5} \mathrm{D}_{0} \rightarrow{ }^{7} \mathrm{~F}_{0}$ transition is always present (as in SI Figure $\mathrm{S} 2 \mathrm{a}$ at $\mathrm{pH} 4.1$ ). Together with the fact that the ${ }^{5} \mathrm{D}_{0} \rightarrow{ }^{7} \mathrm{~F}_{2}$ peak is the most prominent one at all $\mathrm{pH}$, this means that $\mathrm{Eu}(\mathrm{III})$ is always bound to the humic acid.

A typical bi-exponential luminescence decay is recorded throughout the $\mathrm{pH}$ range, with a short luminescence decay time $\left(\tau_{1}<70 \mu\right.$ s) and a longer one $\left(120<\tau_{2}<250 \mu\right.$ s), as previously seen ${ }^{19-22}$ (Figure 4). The first decay time is shorter than free aqueous $\mathrm{Eu}^{3+}(\tau \approx 114 \mu \mathrm{s})^{50}$ and independent of $\mathrm{pH}$, which suggests that this phenomenon barely depends on the chemical environment of $\mathrm{Eu}(\mathrm{III})$ and may be due to a fast exchange between $\mathrm{Eu}(\mathrm{III})$ and humic $\operatorname{acid}^{22,55}$. When $\mathrm{pH}$ increases, $\tau_{2}$ continuously increases, from $137 \pm 2 \mu$ s at $\mathrm{pH} 4.4$ to $246 \pm 42 \mu \mathrm{s}$ at $\mathrm{pH} 8.5$, which means that water molecules are progressively excluded from the coordination sphere of $\mathrm{Eu}(\mathrm{III})$ when $\mathrm{pH}$ increases. 
Ternary System. A comparable ternary system was studied by Tan et al. by TRLS at $\mathrm{pH} 6.3$ on hydrous alumina (mixture of bayerite, boehmite, and diaspore) and Chinese soil $\mathrm{HA} / \mathrm{FA}^{26}$. The direct comparison of the ${ }^{7} \mathrm{~F}_{2} /{ }^{7} \mathrm{~F}_{1}$ ratios may not be done $^{20}$, but the trends can be compared. Recalculated ${ }^{7} \mathrm{~F}_{2} /{ }^{7} \mathrm{~F}_{1}$ from Tan et al. ${ }^{26}$ are equal to 2.0 in their Eu/hydrous alumina system and 5.0 in their Eu/HA system. In their ternary system, this value is equal to 4.8 , which is similar to the $\mathrm{Eu} / \mathrm{HA}$ binary system. Therefore, no change in $\mathrm{Eu}(\mathrm{III})$ environment is expected between the HAcontaining systems.

Here this behavior is probed for a wider $\mathrm{pH}$ range. The ${ }^{7} \mathrm{~F}_{2} /{ }^{7} \mathrm{~F}_{1}$ ratios of ternary $\mathrm{Eu}(\mathrm{III}) / \mathrm{PAHA} / \alpha-\mathrm{Al}_{2} \mathrm{O}_{3}$ system are much more important than in $\mathrm{Eu}(\mathrm{III}) / \alpha-\mathrm{Al}_{2} \mathrm{O}_{3}$ system, and are slightly increasing from 3.0 at $\mathrm{pH} 4.3$ to 4.0 at $\mathrm{pH}$

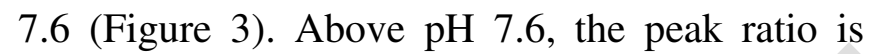
constant, but there is a shift from 615 to $617 \mathrm{~nm}$ of ${ }^{5} \mathrm{D}_{0} \rightarrow{ }^{7} \mathrm{~F}_{2}$ maxima accompanied with a change in peak shape (SI Figure S4), indicating a further change in $\mathrm{Eu}$ (III) chemical environment. At $\mathrm{pH}<$ 7 , the ${ }^{7} \mathrm{~F}_{2} /{ }^{7} \mathrm{~F}_{1}$ ratios of binary $\mathrm{Eu}(\mathrm{III}) / \mathrm{PAHA}$ or ternary $\mathrm{Eu}(\mathrm{III}) / \mathrm{PAHA} / \alpha-\mathrm{Al}_{2} \mathrm{O}_{3}$ systems are very close, as it was for Tan et al. at $\mathrm{pH} 6.3^{26}$. It seems that Eu(III) has a very similar environment in both systems, whether it is in binary $\mathrm{Eu}(\mathrm{III}) / \mathrm{PAHA}$ or sorbed with PAHA onto $\alpha-\mathrm{Al}_{2} \mathrm{O}_{3}$ in ternary system. This would suggest that throughout this $\mathrm{pH}$ range $\mathrm{Eu}(\mathrm{III})$ is directly linked to sorbed humic aggregates and has a limited access to the aluminol surface sites. Conversely, Tan et al. ${ }^{26}$ reported based on XPS that Eu(III) was fixed to both components in the ternary system. This is not apparent here, as it was not in their TRLS spectra.

As shown in Figure 4, there is a bi-exponential decay in the ternary system (see SI Figure S5), which first decay time is directly comparable to the one in $\mathrm{Eu}(\mathrm{III}) / \mathrm{PAHA}$ system. This fast deexcitation is another direct indication that $\mathrm{Eu}(\mathrm{III})$ is strongly linked to sorbed humic aggregates.
These results also suggest that sorbed $\mathrm{Eu}(\mathrm{III})$ in the ternary system is always bound to the sorbed humic acid entities, even at high $\mathrm{pH}$ when humic acid sorption is the lowest (Figure 1).

The values of the longer decay time $\tau_{2}$, from 382 $\pm 55 \mu$ s at $\mathrm{pH} 4.4$ to $308 \pm 25 \mu \mathrm{s}$ at $\mathrm{pH} 8.0$, are more important for the ternary system than for both binary systems, i.e. between 120 and $212 \mu$ s. This is not directly comparable to the results from Tan et al. ${ }^{26}$ who observed a decrease in the decay time between the binary Eu/hydrous alumina, i.e. $219 \mu$ s, and ternary, i.e. $163 \mu \mathrm{s}$; and an increase between the binary Eu/HA, i.e. $111 \mu \mathrm{s}$, and ternary. These authors did not report the typical bi-exponential decay in the presence of HA, maybe because of too long delay step (viz. $15 \mu \mathrm{s}$ for $\mathrm{Eu} / \mathrm{HA}$, and $35 \mu \mathrm{s}$ for $\mathrm{Eu} / \mathrm{HA} /$ hydrous alumina), which already had precluded the determination of bi-exponential decay in past studies $^{56}$. Nevertheless, the increase of luminescence decay time between the binary $\mathrm{Eu} / \mathrm{HA}$ and ternary Eu/HA/hydrous alumina system was observed both in Tan et al. ${ }^{26}$ and in this study. One can also compare the results on the basis of the mass of HA per surface of oxide in both systems. Tan et al. ${ }^{26}$ used $0.02 \mathrm{mg}_{\mathrm{HA}} / \mathrm{m}^{2}(10$ $\mathrm{mg}_{\mathrm{HA}} / \mathrm{L}$ for $4.4 \mathrm{~g} / \mathrm{L}$ hydrous alumina with specific area of $105 \mathrm{~m}^{2} / \mathrm{g}$ ) when we were using 1.86 $\mathrm{mg}_{\mathrm{HA}} / \mathrm{m}^{2}$. The lesser amount of mineral surface could be an explanation for these differences, as well as for the interaction with alumina evidenced by $\mathrm{XPS}^{26}$.

Assuming that $\tau_{1}$ is due to a fast exchange mechanism and $\tau_{2}$ is due to complexation environment, according to reference 52 it would mean that there is only 2 water molecules remaining in the first coordination sphere of $\mathrm{Eu}(\mathrm{III})$ in $\mathrm{Eu}(\mathrm{III}) / \mathrm{PAHA} / \alpha-\mathrm{Al}_{2} \mathrm{O}_{3}$ system at $\mathrm{pH}$ 4.4, when there would be 7 in the $\mathrm{Eu}(\mathrm{III}) / \mathrm{PAHA}$ system at the very same $\mathrm{pH}$. Knowing the reserves on the applicability of this relationship to this 
particular case we cannot take this value for granted.

At low $\mathrm{pH}$, the spectrum in the ternary system is almost the same as the spectrum of Eu-PAHA complex, and very different from the one of $\mathrm{Eu}$ (III) in contact with $\alpha-\mathrm{Al}_{2} \mathrm{O}_{3}$ (SI Figure $\mathrm{S} 2 \mathrm{a}$ ). The spectroscopic and macroscopic data lead us to think that, at $\mathrm{pH}<7$, Eu-PAHA complexes are sorbed onto $\alpha-\mathrm{Al}_{2} \mathrm{O}_{3}$ surface. The increase in $\tau_{2}$ may then be due to a more constrained environment of $\mathrm{Eu}(\mathrm{III})$, but of the same symmetry, in the sorbed humic structure, which may decrease the probability of the Eu(III) ions to lose energy through quenching moieties.

When $\mathrm{pH}$ is increasing, the slower decay time $\tau_{2}$ decreases from $382 \mu \mathrm{s}$ at $\mathrm{pH} 4.4$ to $185 \mu \mathrm{s}$ at $\mathrm{pH}$ 9.6, which means that there is a greater probability of $\mathrm{Eu}$ (III) to be submitted to quenching process when PAHA is less sorbed onto the surface, or that $\mathrm{Eu}$ is progressively more exposed to quenching groups. One can also consider the fractionation of humic acid during sorption. After the $\mathrm{pH}$-edge there is a small decrease in $\mathrm{Eu}(\mathrm{III})$ sorption in the ternary system (Figure 2). This is in fact reflecting the progressive change in the

\section{References}

(1) McCarthy, J. F.; Czerwinski, K. R.; Sanford, W. E.; Jardine, P. M.; Marsh, J. D. Mobilization of Transuranic Radionuclides from Disposal Trenches by Natural Organic Matter. Journal of Contaminant Hydrology $\quad \mathbf{1 9 9 8}, \quad 30 \quad(1-2), \quad 49-77$. https://doi.org/10.1016/S0169-7722(97)00032-6.

(2) McCarthy, J. F.; Sanford, W. E.; Stafford, P. L. Lanthanide Field Tracers Demonstrate Enhanced Transport of Transuranic Radionuclides by Natural Organic Matter. Environ. Sci. Technol. 1998, 32 (24), 3901-3906. https://doi.org/10.1021/es971004f.

(3) Christl, I.; Kretzschmar, R. Interaction of Copper and Fulvic Acid at the Hematite-Water Interface. Geochimica et Cosmochimica Acta 2001, 65 (20), 3435-3442. https://doi.org/10.1016/S00167037(01)00695-0. structure of Eu(III)/PAHA sorbed onto the surface and the competition of $\mathrm{Eu}(\mathrm{III})$ with dissolved PAHA. At $\mathrm{pH}$ greater than 8.5, the ${ }^{5} \mathrm{D}_{0} \rightarrow{ }^{7} \mathrm{~F}_{1}$ transition of the binary $\mathrm{Eu}(\mathrm{III}) / \alpha-\mathrm{Al}_{2} \mathrm{O}_{3}$ and the ternary systems are the same (SI Figure S2b), giving indication that alumina has a direct influence on $\mathrm{Eu}(\mathrm{III})$ environment. Above $\mathrm{pH} 8$, influence of the mineral surface and possible ternary complexes should be taken into account when trying to model such a system.

Acknowledgments This work was financed through the MRISQ (DEN/DISN/AvC) project of CEA. This is IPGP contribution 3089.

\section{Supporting Information Available}

Five figures show Eu(III) luminescence spectra in contact with different concentration of PAHA at $\mathrm{pH} \approx 4, \mathrm{Eu}(\mathrm{III})$ luminescence spectra in the different systems at $\mathrm{pH} \approx 4.2$ and 8.7, inorganic and humic $\mathrm{Eu}(\mathrm{III})$ speciation in solution as a function of $\mathrm{pH}$, evolution of $\mathrm{Eu}$ (III) luminescence spectra in the ternary system at three different $\mathrm{pH}$, and luminescence decay of $\mathrm{Eu}(\mathrm{III})$ in the ternary system at $\mathrm{pH}$ 4.4. This material is available free of charge via the Internet at http://pubs.acs.org.

(4) Vermeer, A. W. P.; McCulloch, J. K.; van Riemsdijk, W. H.; Koopal, L. K. Metal Ion Adsorption to Complexes of Humic Acid and Metal Oxides: Deviations from the Additivity Rule. Environ. Sci. Technol. 1999, $33 \quad$ (21), 3892-3897. https://doi.org/10.1021/es990260k.

(5) Weng, L.; Van Riemsdijk, W. H.; Hiemstra, T. $\mathrm{Cu} 2+$ and $\mathrm{Ca} 2+$ adsorption to Goethite in the Presence of Fulvic Acids. Geochimica et Cosmochimica Acta 2008, $\quad 72 \quad$ (24), 5857-5870. https://doi.org/10.1016/j.gca.2008.09.015.

(6) Heidmann, I.; Christl, I.; Kretzschmar, R. Sorption of $\mathrm{Cu}$ and $\mathrm{Pb}$ to Kaolinite-Fulvic Acid Colloids: Assessment of Sorbent Interactions. Geochimica et Cosmochimica Acta 2005, 69 (7), 1675-1686. https://doi.org/10.1016/j.gca.2004.10.002. 
(7) Schulthess, C. P.; McCarthy, J. F. Competitive Adsorption of Aqueous Carbonic and Acetic Acids by an Aluminum Oxide. Soil Science Society of America Journal 1990, $54 \quad$ (3), 688-694. https://doi.org/10.2136/sssaj1990.03615995005400030 009x.

(8) Schlautman, M. A.; Morgan, J. J. Adsorption of Aquatic Humic Substances on Colloidal-Size Aluminum Oxide Particles: Influence of Solution Chemistry. Geochimica et Cosmochimica Acta 1994, 58 (20), 4293-4303. https://doi.org/10.1016/00167037(94)90334-4.

(9) Filius, J. D.; Lumsdon, D. G.; Meeussen, J. C. L.; Hiemstra, T.; Van Riemsdijk, W. H. Adsorption of Fulvic Acid on Goethite. Geochimica et Cosmochimica Acta 2000, $64 \quad$ (1), 51-60. https://doi.org/10.1016/S0016-7037(99)00176-3.

(10) Weng; Van Riemsdijk, W. H.; Koopal, L. K.; Hiemstra, T. Adsorption of Humic Substances on Goethite: Comparison between Humic Acids and Fulvic Acids Environ. Sci. Technol. 2006, 40 (24), 7494-7500. https://doi.org/10.1021/es060777d.

(11) Murphy, E. M.; Zachara, J. M.; Smith, S. C.; Phillips, J. L.; Wietsma, T. W. Interaction of Hydrophobic Organic Compounds with MineralBound Humic Substances. Environ. Sci. Technol. 1994, $28 \quad$ (7), $1291-1299$. https://doi.org/10.1021/es00056a017.

(12) Lippold, H.; Lippmann-Pipke, J. Effect of Humic Matter on Metal Adsorption onto Clay Materials: Testing the Linear Additive Model. Journal of Contaminant Hydrology 2009, 109 (1-4), 40-48. https://doi.org/10.1016/j.jconhyd.2009.07.009.

(13) MacCarthy, P. THE PRINCIPLES OF HUMIC SUBSTANCES. Soil Science 2001, 166 (11), 738-751. https://doi.org/10.1097/00010694-200111000-00003.

(14) Rice, J. A.; Lin, J. S. Fractal Nature of Humic Materials. Environmental science \& technology 1993, 27 (2), 413-414.

(15) Conte, P.; Piccolo, A. Conformational Arrangement of Dissolved Humic Substances. Influence of Solution Composition on Association of Humic Molecules. Environ. Sci. Technol. 1999, 33 (10), 1682-1690. https://doi.org/10.1021/es9808604.

(16) Hur, J.; Schlautman, M. A. Molecular Weight Fractionation of Humic Substances by Adsorption onto Minerals. Journal of Colloid and Interface Science 2003, 264 (2), 313-321. https://doi.org/10.1016/S0021-9797(03)00444-2.
(17) Claret, F.; Schäfer, T.; Brevet, J.; Reiller, P. E. Fractionation of Suwannee River Fulvic Acid and Aldrich Humic Acid on $\alpha-\mathrm{Al}_{2} \mathrm{O}_{3}$ : Spectroscopic Evidence. Environ. Sci. Technol. 2008, 42 (23), 8809 8815. https://doi.org/10.1021/es801257g.

(18) Thomason, J. W.; Susetyo, W.; Carreira, L. A. Fluorescence Studies of Metal-Humic Complexes with the Use of Lanthanide Ion Probe Spectroscopy. Appl Spectrosc 1996, $50 \quad$ (3), 401-408. https://doi.org/10.1366/0003702963906203.

(19) Kumke, M. U.; Eidner, S.; Krüger, T. Fluorescence Quenching and Luminescence Sensitization in Complexes of $\mathrm{Tb}^{3+}$ and $\mathrm{Eu}{ }^{3+}$ with Humic Substances. Environ. Sci. Technol. 2005, 39 (24), 9528-9533. https://doi.org/10.1021/es051437f.

(20) Brevet, J.; Claret, F.; Reiller, P. E. Spectral and Temporal Luminescent Properties of Eu(III) in Humic Substance Solutions from Different Origins. Spectrochimica Acta Part A: Molecular and Biomolecular Spectroscopy 2009, 74 (2), 446-453. https://doi.org/10.1016/j.saa.2009.06.042.

(21) Marang, L.; Eidner, S.; Kumke, M. U.; Benedetti, M. F.; Reiller, P. E. Spectroscopic Characterization of the Competitive Binding of $\mathrm{Eu}(\mathrm{III}), \mathrm{Ca}(\mathrm{II})$, and $\mathrm{Cu}$ (II) to a Sedimentary Originated Humic Acid. Chemical Geology 2009, 264 (1-4), 154-161. https://doi.org/10.1016/j.chemgeo.2009.03.003.

(22) Reiller, P. E.; Brevet, J. Bi-Exponential Decay of Eu(III) Complexed by Suwannee River Humic Substances: Spectroscopic Evidence of Two Different Excited Species. Spectrochimica Acta Part A: Molecular and Biomolecular Spectroscopy 2010, 75 (2), 629-636. https://doi.org/10.1016/j.saa.2009.11.029.

(23) Marang, L.; Reiller, P. E.; Eidner, S.; Kumke, M. U.; Benedetti, M. F. Combining Spectroscopic and Potentiometric Approaches to Characterize Competitive Binding to Humic Substances. Environ. Sci. Technol. 2008, 42 (14), 5094-5098. https://doi.org/10.1021/es702858p.

(24) Huittinen, N.; Rabung, Th.; Lützenkirchen, J.; Mitchell, S. C.; Bickmore, B. R.; Lehto, J.; Geckeis, H. Sorption of $\mathrm{Cm}(\mathrm{III})$ and $\mathrm{Gd}(\mathrm{III})$ onto Gibbsite, $\alpha$ $\mathrm{Al}(\mathrm{OH}) 3$ : A Batch and TRLFS Study. Journal of Colloid and Interface Science 2009, 332 (1), 158-164. https://doi.org/10.1016/j.jcis.2008.12.017.

(25) Rabung, Th.; Pierret, M. C.; Bauer, A.; Geckeis, H.; Bradbury, M. H.; Baeyens, B. Sorption of $\mathrm{Eu}(\mathrm{III}) / \mathrm{Cm}$ (III) on Ca-Montmorillonite and Na-Illite. 
Part 1: Batch Sorption and Time-Resolved Laser Fluorescence Spectroscopy Experiments. Geochimica et Cosmochimica Acta 2005, 69 (23), 5393-5402. https://doi.org/10.1016/j.gca.2005.06.030.

(26) Tan, X. L.; Wang, X. K.; Geckeis, H.; Rabung, Th. Sorption of Eu(III) on Humic Acid or Fulvic Acid Bound to Hydrous Alumina Studied by SEM-EDS, XPS, TRLFS, and Batch Techniques. Environ. Sci. Technol. 2008, 42 (17), 6532-6537. https://doi.org/10.1021/es8007062.

(27) Kim, J.-I.; Buckau, G.; Li, G. H.; Duschner, H.; Psarros, N. Characterization of Humic and Fulvic Acids from Gorleben Groundwater. Fresenius' Journal of Analytical Chemistry 1990, 338 (3), 245-252. https://doi.org/10.1007/BF00323017.

(28) Janot, N.; Reiller, P. E.; Korshin, G. V.; Benedetti, M. F. Using Spectrophotometric Titrations To Characterize Humic Acid Reactivity at Environmental Concentrations. Environ. Sci. Technol. 2010, 44 (17), 6782-6788. https://doi.org/10.1021/es1012142.

(29) Alliot, C.; Bion, L.; Mercier, F.; Vitorge, P.; Toulhoat, P. Effect of Aqueous Acetic, Oxalic and Carbonic Acids on the Adsorption of Americium onto $\alpha$-Alumina. Radiochimica Acta 2005, 93 (8). https://doi.org/10.1524/ract.2005.93.8.435.

(30) Milne, C. J.; Kinniburgh, D. G.; van Riemsdijk, W. H.; Tipping, E. Generic NICA-Donnan Model Parameters for Metal-Ion Binding by Humic Substances. Environ. Sci. Technol. 2003, 37 (5), 958971. https://doi.org/10.1021/es0258879.

(31) Bünzli, J.-C. Luminescent Probes. In Lanthanides Probe in Life, Chemical and Earth Sciences-Theory and Practice; Amsterdam, 1989; pp 219-293.

(32) Judd, B. R. Optical Absorption Intensities of Rare-Earth Ions. Phys. Rev. 1962, 127 (3), 750-761. https://doi.org/10.1103/PhysRev.127.750.

(33) Ofelt, G. S. Intensities of Crystal Spectra of RareEarth Ions. The Journal of Chemical Physics 1962, 37 (3), 511-520. https://doi.org/10.1063/1.1701366.

(34) Berthoud, T.; Decambox, P.; Kirsch, B.; Mauchien, P.; Moulin, C. Direct Determination of Traces of Lanthanide Ions in Aqueous Solutions by Laser-Induced Time-Resolved Spectrofluorimetry. Analytica Chimica Acta 1989, 220, 235-241. https://doi.org/10.1016/S0003-2670(00)80266-4.

(35) Reiller, P.; Moulin, V.; Casanova, F.; Dautel, C. Retention Behaviour of Humic Substances onto Mineral Surfaces and Consequences upon Thorium
(IV) Mobility: Case of Iron Oxides. Applied Geochemistry 2002, 17 (12), 1551-1562. https://doi.org/10.1016/S0883-2927(02)00045-8.

(36) Varadachari, C.; Chattopadhyay, T.; Ghosh, K. Complexation of Humic Substances with Oxides of Iron and Aluminum. Soil Science 1997, 162 (1), 2834.

(37) Křepelová, A.; Sachs, S.; Bernhard, G. Uranium(VI) Sorption onto Kaolinite in the Presence and Absence of Humic Acid. Radiochimica Acta 2006, 94 (12). https://doi.org/10.1524/ract.2006.94.12.825.

(38) Avena, M. J.; Vermeer, A. W. P.; Koopal, L. K. Volume and Structure of Humic Acids Studied by Viscometry PH and Electrolyte Concentration Effects. Colloids and Surfaces A: Physicochemical and Engineering Aspects 1999, 151, 213-224.

(39) Rice, J. A.; Tombacz, E.; Malekani, K. Applications of Light and X-Ray Scattering to Characterize the Fractal Properties of Soil Organic Matter. Geoderma 1999, 88, 251-264.

(40) Caceci, M. S.; Moulin, V. Investigation of Humic Acid Samples from Different Sources by Photon Correlation Spectroscopy. In Humic Substances in the Aquatic and Terrestrial Environment; Allard, B., Borén, H., Grimvall, A., Eds.; Lecture Notes in Earth Sciences; Springer: Berlin, Heidelberg, 1991; pp $97-$ 104. https://doi.org/10.1007/BFb0010461.

(41) Plaschke, M.; Rothe, J.; Schäfer, T.; Denecke, M. A.; Dardenne, K.; Pompe, S.; Heise, K.-H. Combined AFM and STXM in Situ Study of the Influence of $\mathrm{Eu}(\mathrm{III})$ on the Agglomeration of Humic Acid. Colloids and Surfaces A: Physicochemical and Engineering Aspects 2002, $197 \quad$ (1-3), 245-256. https://doi.org/10.1016/S0927-7757(01)00901-3.

(42) Fairhurst, A. J.; Warwick, P. The Influence of Humic Acid on Europium-Mineral Interactions. Colloids and Surfaces A: Physicochemical and Engineering Aspects 1998, 145 (1-3), 229-234. https://doi.org/10.1016/S0927-7757(98)00662-1.

(43) Fairhurst, A. J.; Warwick, P.; Richardson, S. The Influence of Humic Acid on the Adsorption of Europium onto Inorganic Colloids as a Function of PH. Colloids and Surfaces A: Physicochemical and Engineering Aspects 1995, 99 (2-3), 187-199. https://doi.org/10.1016/0927-7757(95)03124-V.

(44) Righetto, L.; Bidoglio, G.; Azimonti, G.; Bellobono, I. R. Competitive Actinide Interactions in Colloidal Humic Acid-Mineral Oxide Systems. 
Environ. Sci. Technol. 1991, 25 (11), 1913-1919. https://doi.org/10.1021/es00023a012.

(45) Hummel, W.; Berner, U.; Curti, E.; Pearson, F. J.; Thoenen, T. Nagra / PSI Chemical Thermodynamic Data Base 01/01; July; Paul Scherrer Institut, 2002.

(46) Bradbury, M. H.; Baeyens, B. Sorption Modelling on Illite Part I: Titration Measurements and the Sorption of $\mathrm{Ni}, \mathrm{Co}, \mathrm{Eu}$ and $\mathrm{Sn}$. Geochimica et Cosmochimica Acta 2009, 73 (4), 990-1003. https://doi.org/10.1016/j.gca.2008.11.017.

(47) Bradbury, M. H.; Baeyens, B. Sorption Modelling on Illite. Part II: Actinide Sorption and Linear Free Energy Relationships. Geochimica et Cosmochimica Acta 2009, 73 (4), 1004-1013. https://doi.org/10.1016/j.gca.2008.11.016.

(48) Keizer, M. G.; van Riemsdijk, W. H. ECOSAT, a Computer Program for the Calculation of Chemical Speciation and Transport in Soil-Water Systems. Wageningen Agricultural University 1995.

(49) Reiller, P.; Casanova, F.; Moulin, V. Influence of Addition Order and Contact Time on Thorium(IV) Retention by Hematite in the Presence of Humic Acids. Environ. Sci. Technol. 2005, 39 (6), 1641-1648. https://doi.org/10.1021/es048856h.

(50) Horrocks, W. DeW.; Sudnick, D. R. Lanthanide Ion Probes of Structure in Biology. Laser-Induced Luminescence Decay Constants Provide a Direct Measure of the Number of Metal-Coordinated Water Molecules. J. Am. Chem. Soc. 1979, 101 (2), 334-340. https://doi.org/10.1021/ja00496a010.

(51) Supkowski, R. M.; Horrocks, W. DeW. On the Determination of the Number of Water Molecules, q, Coordinated to Europium(III) Ions in Solution from Luminescence Decay Lifetimes. Inorganica Chimica Acta 2002, 340, 44-48. https://doi.org/10.1016/S00201693(02)01022-8.

(52) Kimura, T.; Kato, Y.; Takeishi, H.; Choppin, G. R. Comparative Study on the Hydration States of $\mathrm{Cm}$ (III) and $\mathrm{Eu}(\mathrm{III})$ in Solution and in Cation Exchange Resin. Journal of Alloys and Compounds 1998, 271-273, 719-722. https://doi.org/10.1016/S0925-8388(98)00194-7.

(53) Takahashi, Y.; Tada, A.; Kimura, T.; Shimizu, H. Formation of Outer- and Inner-Sphere Complexes of Lanthanide Elements at Montmorillonite-Water Interface. Chem. Lett. 2000, 29 (6), 700-701. https://doi.org/10.1246/cl.2000.700.

(54) Morgenstern, M.; Klenze, R.; Kim, J. I. The Formation of Mixed-Hydroxo Complexes of $\mathrm{Cm}(\mathrm{III})$ and Am(III) with Humic Acid in the Neutral PH Range. Radiochimica Acta 2000, 88 (1). https://doi.org/10.1524/ract.2000.88.1.007.

(55) Freyer, M.; Walther, C.; Stumpf, T.; Buckau, G.; Fanghänel, T. Formation of $\mathrm{Cm}$ Humate Complexes in Aqueous Solution at PHc 3 to 5.5: The Role of Fast Interchange. Radiochimica Acta 2009, 97 (10). https://doi.org/10.1524/ract.2009.1628.

(56) Plancque, G.; Moulin, V.; Toulhoat, P.; Moulin, C. Europium Speciation by Time-Resolved LaserInduced Fluorescence. Analytica Chimica Acta 2003, 478 (1), 11-22. https://doi.org/10.1016/S00032670(02)01486-1. 